\title{
Pemberdayaan Kader Posyandu Lansia Pada Masa Pandemi Covid-19
}

\section{Ikhlas Muhammad Jenie ${ }^{1}$, Zulkhah Noor', Maya Um Husna², Muhammad Herjuna', Lutfi Putra Perdana1}

Faculty of Medicine and Health Sciences, Universitas Muhammadiyah Yogyakarta, Jl. Brawijaya, Tamantirto, Kasihan, Bantul, Daerah Istimewa Yogyakarta, 55183.

Rumah Sakit Umum Daerah Sleman, Jalan Bhayangkara 48, Triharjo, Sleman, Daerah Istimewa Yogyakarta, 55514.

Jalan Ireda no. 68, Yogyakarta, 55152

Email: ikhlas.muhammad@umy.ac.id

DOI: $10.18196 / p p m \cdot 32.178$

\begin{abstract}
Abstrak
Pos pelayanan terpadu (posyandu) mengalami vakum kegiatan semenjak pandemi Corona Virus Disease-2019 (Covid-19). Walikota Yogyakarta menerbitkan surat edaran mengenai operasional Posyandu di masa pandemi Covid-19 dengan protokol kesehatan. Pusat Kesehatan Masyarakat (Puskesmas) Mergangsan menunjuk Posyandu Keji Beling RW 05 Kampung Pujokusuman sebagai posyandu pertama di lingkungan Kecamatan Mergangsan Kota Yogyakarta untuk menyelenggarakan posyandu lanjut usia (lansia) dengan protokol kesehatan. Tujuan kegiatan pengabdian masyarakat ini adalah mempersiapkan dan mendampingi kader kesehatan posyandu Keji Beling untuk dapat menyelenggarakan posyandu lansia di masa pandemi Covid-19. Metode pengabdian pada kegiatan pertama adalah dengan ceramah. Kader posyandu diberikan refreshing pengetahuan mengenai landasan hukum penanganan wabah penyakit menular di Indonesia, usaha-usaha untuk meningkatkan imunitas tubuh, panduan pencegahan dan pengendalian Covid-19 dari Kementrian Kesehatan Republik Indonesia, serta pembagian hand sanitizer dan face shield. Metode pengabdian pada kegiatan kedua adalah pendampingan kegiatan lapangan dalam pelaksanaan posyandu lansia di masa pandemi Covid19. Posyandu Lansia Keji Beling pada masa pandemi Covid-19 dilaksanakan dengan membatasi jumlah peserta (25\%) dan kader posyandu (50\%). Peserta posyandu lansia yang diundang berjumlah 17 orang, terdiri atas 4 laki-laki (24\%) dan 13 perempuan (76\%) dengan rentang usia 60-69 tahun 11 orang (65\%), 70-79 tahun 5 orang (29\%), dan 80-89 tahun 1 orang (6\%). Pemeriksaan kesehatan lansia meliputi penimbangan berat badan, pengukuran tekanan darah, pemeriksaan kadar glukosa darah sewaktu dan kadar kolesterol. Hasilnya adalah prevalensi hiperkolesterolemia 53\%, hipertensi $47 \%$, obesitas $12 \%$, dan diabetes 5,9\%. Kesimpulannya adalah posyandu lansia dapat terselenggara pada masa pandemi Covid-19 melalui pemberdayaan kader posyandu, pembatasan jumlah peserta, dan penerapan protokol kesehatan.
\end{abstract}

Kata Kunci: pemberdayaan kader posyandu, posyandu lansia, protokol kesehatan, pandemi Covid-19, imunitas tubuh

Pendahuluan

UU Nomor 13 tahun 1998 tentang Kesejahteraan Lanjut Usia mendefinisikan lanjut usia (lansia) sebagai seseorang yang mencapai usia 60 tahun atau lebih (Sekretaris Negara RI, 1998). Jumlah populasi lansia secara global dan di Indonesia terus mengalami peningkatan. Peningkatan proporsi penduduk lansia $\geq 10 \%$ menyebabkan perubahan struktur penduduk menuju struktur penduduk tua (ageing population). Struktur penduduk tua merupakan cerminan dari semakin tingginya rata-rata Usia Harapan Hidup (UHH) penduduk Indonesia. Tingginya UHH merupakan salah satu indikator keberhasilan pencapaian pembangunan nasional, terutama di bidang kesehatan. Ada peningkatan UHH di Indonesia dari 69 tahun pada tahun 2009 menjadi 70,8 tahun pada tahun 2015 (Darmoho \& Martono, 2015).

Berdasarkan data sebaran penduduk lansia dilihat dari provinsinya, Daerah Istimewa Yogyakarta (DIY) adalah provinsi dengan proporsi lansia tertinggi $(13,4 \%)$ di Indonesia (Kementrian Kesehatan RI, 2018). Dengan demikian, struktur penduduk Provinsi DIY termasuk struktur penduduk tua. Posyandu Keji Beling merupakan pos pelayanan terpadu dalam bidang kesehatan milik warga masyarakat RW 05 Kampung Pujokusuman, Kelurahan Keparakan, Kecamatan Mergangsan, Kota Yogyakarta, Provinsi Daerah Istimewa Yogyakarta. Posyandu tersebut dibentuk pada tahun 2000. Posyandu Keji Beling memiliki anggota 49 lansia, yaitu 28 orang perempuan $(57,14 \%)$ dan 21 orang laki-laki $(42,86 \%)$. Pelayanan kesehatan lansia atau 
lanjut usia meliputi penimbangan berat badan, pengukuran tekanan darah, konsutasi kesehatan, dan pemberian makanan tambahan (Posyandu Keji Beling, 2010).

Pada tanggal 31 Desember 2019, WHO China Country Office melaporkan kasus pneumonia yang tidak diketahui etiologinya di Kota Wuhan, Provinsi Hubei, Cina. Pada tanggal 7 Januari 2020, China mengidentifikasi kasus tersebut sebagai jenis baru virus corona, yaitu Severe Acute Respiratory Syndrome Coronavirus 2 (SARS-CoV-2) yang menyebabkan Coronavirus Disease 2019 (Covid-19). Pada tanggal 30 Januari 2020, WHO menetapkan kejadian tersebut sebagai Kedaruratan Kesehatan Masyarakat yang Meresahkan Dunia (KKMMD) dan pada tanggal 11 Maret 2020 WHO menetapkan Covid-19 sebagai pandemi (Kementrian Kesehatan RI, 2020).

Tanda dan gejala umum infeksi Covid-19 antara lain gejala gangguan pernapasan akut, seperti demam, batuk, dan sesak napas. Masa inkubasi rata-rata 5-6 hari dengan masa inkubasi terpanjang 14 hari. Kasus Covid-19 yang berat dapat menyebabkan pneumonia, sindrom pernapasan akut, gagal ginjal, bahkan kematian. Indonesia melaporkan kasus pertama Covid-19 pada tanggal 2 Maret 2020 dan jumlahnya terus bertambah hingga sekarang. Sampai dengan tanggal 18 Oktober 2020 Kementerian Kesehatan melaporkan 361.867 kasus konfirmasi Covid19 dengan 12.511 kasus meninggal (CFR 3,45\%) yang tersebar di 34 provinsi (Kementrian Kesehatan RI, 2020; Susilo et al., 2020).

Semenjak pandemi Covid-19, Posyandu Keji Beling mengalami vakum kegiatan. Hal ini menyebabkan pemantauan kesehatan lansia di RW 05 Kampung Pujokusuman Yogyakarta menjadi terlantar. Syukur alhamdulillah, terbit Peraturan Walikota Yogyakarta Nomor 51 tahun 2020 tentang Pedoman Pencegahan dan Pengendalian Corona Virus Disease-19 pada masa tatanan normal baru di Kota Yogyakarta (Walikota Yogyakarta DIY, 2020). Surat edaran ini menimbulkan semangat bagi Kader Posyandu Keji Beling untuk menerapkan Posyandu Lansia di era pandemi Covid-19.

Tujuan Program Pengabdian Masyarakat ini adalah untuk membantu kader Posyandu Keji Beling untuk mempersiapkan dan menyelenggarakan Posyandu Lansia di masa pandemi Covid19.

\section{Metode Pelaksanaan}

Untuk melaksanakan Posyandu Lansia Keji Beling di era pandemi Covid-19, dilakukan dua kegiatan, yaitu 1) persiapan kader Posyandu Keji Beling, dan 2) pelaksanaan Posyandu Lansia di era pandemi Covid-19.

Persiapan kader Posyandu Lansia berupa refreshing pengetahuan kader Posyandu Lansia mengenai penanggulangan wabah Covid-19, protokol kesehatan, dan usaha-usaha untuk meningkatkan sistem imun tubuh. Selain refreshing pengetahuan, kepada kader Posyandu Lansia juga dibagikan hand sanitizer dan face shield. Kepada Posyandu Keji Beling diberikan alat pengukur tekanan darah Omron dan thermogun.

Pelaksanaan Posyandu Lansia di era pandemi Covid-19 dilaksanakan dengan pembatasan jumlah peserta dan kader posyandu, penerapan protokol kesehatan, dan pemeriksaan kesehatan lansia. Pembatasan jumlah peserta sebesar $25 \%$ dan kader posyandu sebesar $50 \%$. Penerapan protokol kesehatan meliputi cuci tangan dengan sabun dan air mengalir, memakai masker, dan jaga jarak (cita mas Jajar), Pemeriksaan kesehatan lansia meliputi penimbangan berat badan, pengukuran tekanan darah, pemeriksaan kadar glukosa darah sewaktu, dan kadar kolesterol. 
Hasil dan Pembahasan

Persiapan kader Posyandu Lansia berupa refreshing pengetahuan diikuti oleh kader Posyandu Lansia Keji Beling berjumlah 15 orang, yang terdiri atas 1 orang ketua dan 14 orang kader posyandu. Materi refreshing diberikan melalui ceramah, meliputi 1) Penanggulangan abah di Indonesia dengan pemateri Dr. dr. Ikhlas Muhammad Jenie dari FKIK UMY; 2) Panduan terkini penanganan Covid-19 yang dikeluarkan oleh Kementrian Kesehatan RI dengan pemateri dr. Maya Um Husna, SpPD dari RSUD Sleman, DIY; dan 3) Peningkatan sistem imun tubuh dengan pemateri drh. Zulkhah Noor, MKes dari FKIK UMY. Pemberian materi (Gambar 1) diikuti dengan sesi diskusi.

Menurut Peraturan Menteri Dalam Negeri Nomor 7 tahun 2007 tentang kader pemberdayaan masyarakat, pemberdayaan masyarakat adalah suatu strategi yang digunakan dalam pembangunan masyarakat sebagai upaya untuk mewujudkan kemampuan dan kemandirian dalam kehidupan bermasyarakat, berbangsa, dan bernegara di bidang ekonomi, sosial-budaya, politik, dan lingkungan hidup (Menteri Dalam Negeri, 2007).

Kader kesehatan masyarakat adalah tenaga sukarela, baik laki-laki maupun perempuan, yang dipilih dan tumbuh di tengah masyarakat serta dilatih untuk menangani masalah kesehatan perorangan dan masyarakat. Pelatihan kader kesehatan merupakan bagian dari pemberdayaan masyarakat di bidang kesehatan. Hal ini sebagai salah satu upaya kunci agar kegiatan pemberdayaan masyarakat di bidang kesehatan dapat berjalan secara berkelanjutan (Andreas, 2000).

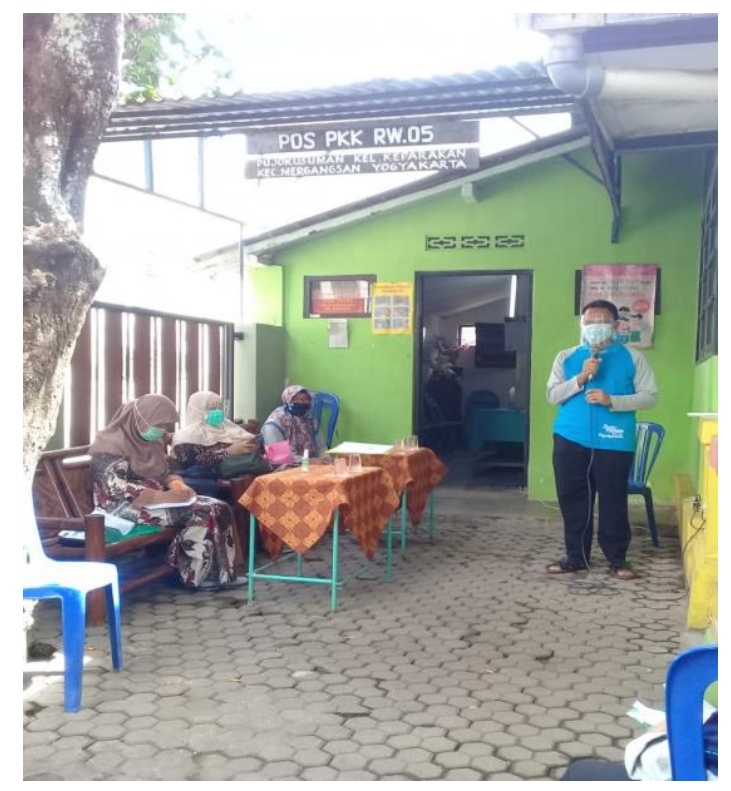

\section{Gambar 1. Ceramah pembekalan kader posyandu Keji Beling mengenai Covid-19}

Screening dan pemeriksaan kesehatan lansia diselenggarakan dalam waktu yang berbeda. Pemeriksaan tersebut meliputi penimbangan berat badan, pengukuran tekanan darah, pemeriksaan kadar glukosa darah sewaktu (GDS), dan kadar kolesterol. Peserta Posyandu Lansia pada masa pandemi Covid-19 berjumlah 17 orang dengan karakteristik sebagai berikut (Tabel 1 dan Gambar 2). 
Tabel 1

Karakteristik Lansia Peserta Posyandu KEJI BELING di Masa Pandemi Covid-19

\begin{tabular}{|l|r|}
\hline Karakteristik & Jumlah (persentase) \\
\hline Jenis kelamin & $-4(24 \%)$ \\
$-\quad$ Laki-laki & $-13(76 \%)$ \\
$-\quad$ Perempuan & \\
\hline Usia (tahun) & $-11(65 \%)$ \\
$-\quad 60-69$ & $-5(29 \%)$ \\
$-\quad 70-79$ & $-1(6 \%)$ \\
$-80-89$ &
\end{tabular}

Dari Tabel 1 terlihat bahwa lansia peserta Posyandu Keji Beling di masa pandemi Covid-19 didominasi jenis kelamin perempuan dan usia di rentang 60-69 tahun.

Tabel 2

Hasil Pemeriksaan Kesehatan Lansia Peserta Posyandu Keji Beling di Masa Pandemi Covid-19 dan Perbandingannya dengan Data Riset Kesehatan Dasar (Riskesdas) 2018

\begin{tabular}{|c|c|}
\hline $\begin{array}{c}\text { Pemeriksaan Kesehatan } \\
\text { Lansia }\end{array}$ & $\begin{array}{c}\text { Prevalensi di Posyandu Keji } \\
\text { Beling 2020 }\end{array}$ \\
\hline Hiperkolesterolemia & $53,0 \%$ \\
\hline Hipertensi & $47,0 \%$ \\
\hline Obesitas & $12,0 \%$ \\
\hline Diabetes & $5,9 \%$ \\
\hline
\end{tabular}

Dari Tabel 2 terlihat bahwa lebih dari separuh penduduk lansia RW 05 Kampung Pujokusuman yang diwakili oleh peserta Posyandu Lansia Keji Beling di Era Pandemi Covid-19 mengalami hiperkolesterolemia. Tabel 2 juga menunjukkan bahwa hampIr separuh penduduk lansia RW 05 Kampung Pujokusuman yang diwakili oleh peserta Posyandu Lansia Keji Beling di Era Pandemi Covid-19 mengalami hipertensi. Tabel 2 juga menunjukkan bahwa penduduk lansia RW 05 Kampung Pujokusuman yang diwakili oleh peserta Posyandu Lansia Keji Beling di Era Pandemi Covid-19 tidak banyak yang mengalami obesitas dan diabetes.

Data Riset Kesehatan Dasar (Riskesdas) (2018) menunjukkan bahwa penyakit tidak menular pada penduduk usia dewasa di Indonesia adalah sebagai berikut (Tabel 3).

Tabel 3

Prevalensi Penyakit Tidak Menular di Indonesia Berdasarkan Data Riskesdas Tahun 2018

\begin{tabular}{|c|c|}
\hline Penyakit Tidak Menular & Prevalensi \\
\hline Hiperkolesterolemia & $44,0 \%$ \\
\hline Hipertensi & $34,0 \%$ \\
\hline
\end{tabular}




\begin{tabular}{|c|r|}
\hline Obesitas & $22,0 \%$ \\
\hline Diabetes & $8,5 \%$ \\
\hline
\end{tabular}

Tabel 2 dan Tabel 3 menunjukkan bahwa urutan hasil pemeriksaan kesehatan lansia pada Posyandu Lansia Keji Beling RW 05 Kampung Pujokusuman, Kota Yogyakarta di masa pandemi Covid-19 sama dengan urutan prevalensi secara nasional dari data Riskesdas 2018, yakni mulai dari tertinggi sampai dengan terendah: hiperkolesterolemia, hipertensi, obesitas, dan diabetes. Hanya saja, prevalensi hiperkolesterolemia dan hipertensi pada penduduk lansia RW 05 Kampung Pujokusuman, Kota Yogyakarta di masa pandemi Covid-19 tahun 2020 ini mengalami peningkatan jika dibandingkan prevalensi nasional tahun 2018. Hasil pemeriksaan kesehatan lansia di Posyandu Lansia Keji Beling RW 05 Kampung Pujokusuman, Kota Yogyakarta perlu ditindak lanjuti dengan usaha-usaha pencegahan dan pengendalian kejadian hiperkolesterolemia, hipertensi, obesitas, dan diabetes pada penduduk lansia RW 05 Kampung Pujokusuman, Kota Yogyakarta.

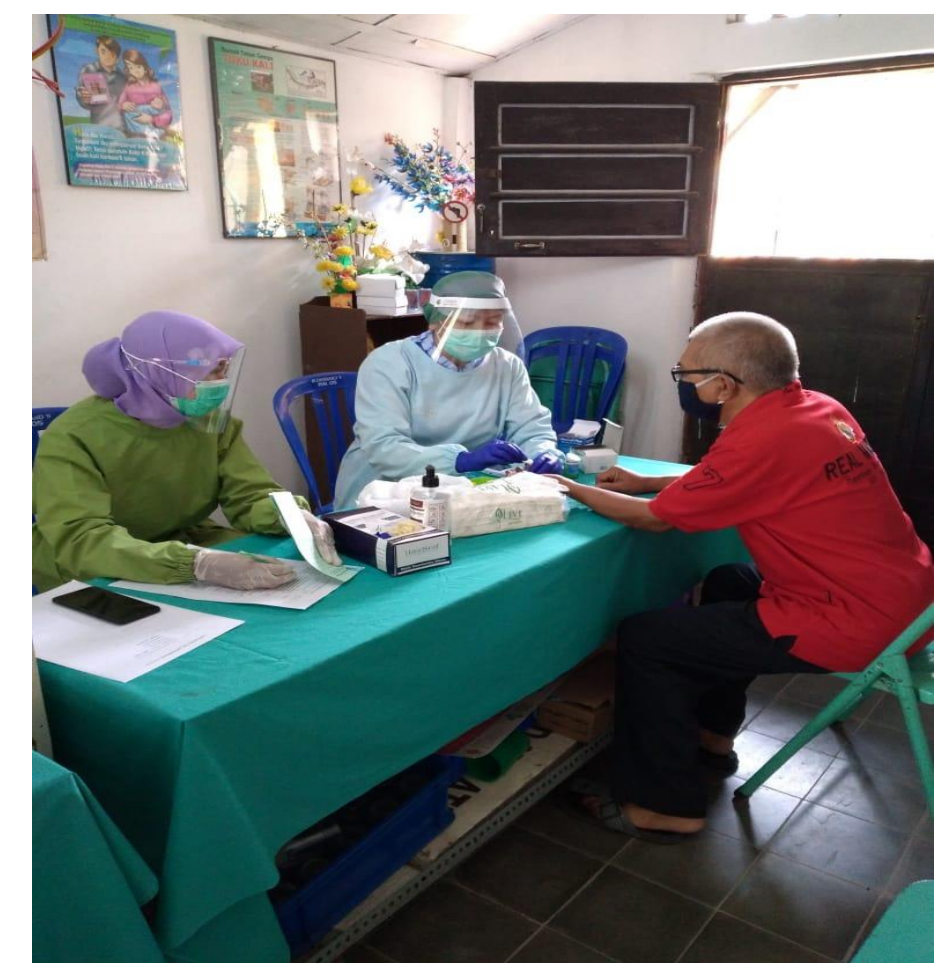

\section{Gambar 2. Pelaksanaan posyandu lansia di masa pandemi Covid 19} di Posyandu Keji Beling

Simpulan

1. Metode ceramah dengan materi penanganan wabah covid-19 efektif membekali kader Posyandu Lansia Keji Beling RW 05 Kampung Pujokusuman, Kelurahan Keparakan, Kecamatan Mergangsan, Kota Yogyakarta sebagai persiapan agar dapat menyelenggarakan posyandu lansia pada masa pandemi Covid-19. 
2. Kegiatan lapangan efektif mendampingi kader posyandu kesehatan Posyandu Lansia Keji Beling dalam menyelenggarakan Posyandu Lansia pada masa pandemi Covid-19 dengan pembatasan jumlah peserta dan penerapan protokol kesehatan.

3. Hasil pemeriksaan kesehatan lansia di Posyandu Lansia Keji Beling RW 05 Kampung Pujokusuman, Kelurahan Keparakan, Kecamatan Mergangsan, Kota Yogyakarta pada masa pandemi Covid-19 sesuai dengan prevalensi nasional untuk hiperkolesterolemia dan hipertensi yang menempati urutan pertama dan kedua.

\section{Ucapan Terima Kasih}

Kami mengucapkan terima kasih kepada:

1. Lembaga Penelitian Publikasi dan Pengabdian Masyarakat Universitas Muhammadiyah Yogyakarta (LP3M UMY) atas pendanaan hibah Pengabdian Masyarakat tahun 2020.

2. Bapak Budi Triono (Ketua RW 05 Kampung Pujokusuman), Ibu Budi Triono (Ketua PKK/Posyandu Keji Beling) beserta seluruh kader Posyandu Lansia Keji Beling RW 05 Kampung Pujokusuman, Kelurahan Keparakan, Kecamatan Mergangsan, Kota Yogyakarta sebagai mitra pengabdian masyarakat yang telah membantu kegiatan ini secara optimal.

Daftar Pustaka

Andreas, P. 2000. Kader kesehatan masyarakat sebagai salah satu bagian dari upaya pengembangan masyarakat. Jurnal Kedokteran Gigi Universitas Indonesia 7 (Edisi Khusus): 304-310.

Darmodjo, B. \& Martono, H. 2015. Buku Ajar Geriatri. Fakultas Kedokteran Universitas Diponegoro.

Kementrian Kesehatan RI. 2018. Data dan Informasi Profil Kesehatan Indonesia. Jakarta.

Kementrian Kesehatan RI. 2020. Pedoman Pencegahan dan Pengendalian Coronavirus Disease (COVID-19). Jakarta.

Menteri Dalam Negeri. 2007. Peraturan Menteri Dalam Negeri Nomor 7 Tahun 2007 Tentang Kader Pemberdayaan Masyarakat. Jakarta.

Pos Pelayanan Terpadu (Posyandu) Keji Beling. 2010. Satu Dasawarsa Posyandu Keji Beling RW 05 Kampung Pujokusuman, Kelurahan Keparakan, Kecamatan Mergangsan, Kota Yogyakarta.

Riset Kesehatan Dasar. 2018. Badan Litbang Kementrian Kesehatan RI. Jakarta.

Susilo, A., Rumende, C.M., Pitoyo, C.V., Santoso, W.D., Yulianti, M., Herikurniawan, et al. 2020. Coronavirus Disease 2019: Tinjauan literatur terkini. Jurnal Penyakit Dalam Indonesia 7 (1): 45-67.

Sekretaris Negara Republik Indonesia. 1998. Undang-Undang Nomor 13 Tahun 1998 tentang Kesejahteraan Lanjut Usia. Jakarta.

Walikota Yogyakarta Daerah Istimewa Yogyakarta (DIY). 2020. Peraturan Walikota Yogyakarta Nomor 51 Tahun 2020 Tentang Pedoman Pencegahan dan Pengendalian Corona Virus Disease-19 pada Masa Tatanan Normal Baru di Kota Yogyakarta. 